\title{
AN ANALYSIS OF PRESUPPOSITION FOUND IN THE GUARDIAN NEWS: PRAGMATICAL APPROACH
}

\author{
Crisnova Katalonika Siahaan, Zia Hisni Mubarak \\ pb161210048@upbatam.ac.id,Zia.hisni@puterabatam.ac.id, \\ info@upbatam.ac.id \\ English Department, Faculty of Social and Humanities, \\ Putera Batam University
}

\begin{abstract}
This paper is qualitative descriptive research which investigates types of presupposition and the mostly used type of presupposition. The data source in this study is utterance in Guardian news. The method of collecting is by observation. The methods of analyzing data are by agih and padan method from Sudaryanto. Author uses theory of Yule which divides presupposition into 6 types these are existential presupposition, factive presupposition, lexical presupposition, structural presupposition, non-factive presupposition, and counterfactual presupposition. The researcher has 20 data here. There are 3 types of presupposition found in the Guardian news. The most used type used is existential presupposition.
\end{abstract}

Keywords: pragmatic; presupposition; utteran

\section{INTRODUCTION}

Language is communication tool that is used to do interaction each other. Pragmatic is the science that examines how the units of language are used in speech in order to carry out communication. According to Abdul Chaer (as cited in Levinson, 1983), pragmatic is the science that examines how the units of language are used in speech in order to carry out communication. One of the things that become a discussion in pragmatics is presupposition. An utterance can be said to presuppose or preach other utterances, if the speech untruth that is presumed results in the truth or speech untruth cannot be said at all. According to Yule (1996). In general it will still be necessary for assumptions, which are placed in the form of statements, rejections, or questions, and can be associated with certain physical items or grammatical features in speeches

Article news can be filled with some presupposition. News is made 
based on public occurence. The term presupposition is used because a sentence turns out to be able to presuppose and imply another sentence. A sentence presupposes another sentence if the untruth of the second sentence (presupposed) results in the first sentence (which presupposes) cannot be said to be true or false. The news which will be researched by author entitled "Three Rebel Armies Fighting for Liberation from Indonesia Join Forces under Movement Headed by Exiled Leader Benny Wenda." This research concerned to discuss the types of presupposition and the mostly used type of presupposition. This research applies the presupposition theory by Yule (1996).

\section{REVIEW OF RELATED LITERATURE}

\subsection{Pragmatic}

Pragmatic is the study of
speaker meaning. It needs a
consideration of how speaker arranges
what they want to convey in
accordance with who they are
speaking to, where, when, and under
what situation. It inquires some
understanding about the facts with
that pragmatics deals these are fact
about the goal of the utterance, when
and where the utterance happens, fact
about the purpose of speaker, and fact
about contention of the speaker and
those to whom speaker talks and what
they talks about.

\subsection{Presupposition}

It refers to the condition that must be met in order for the intended meaning of a sentence to be regarded as acceptable. It comes from the word to pre-suppose, which in English means to suppose beforehand, in the sense that before the speaker or writer says something he already has a previous expectation about the other person or person being discussed. Those who have presuppositions are speakers, not sentences.

\subsection{Types of Presupposition}

\subsubsection{Existential Presupposition}

Existential presuppositions show how the existence of things can be conveyed through presupposition. Example: Someone stole Andi's motorcycle.

The presuppositions in the utterance state the existence, namely:

(a) There is a motorbike.

(b) There are thieves.

(c) There is a person named Andi.

\subsubsection{Factive Presupposition}

This presupposition is acquired by some verbs which can give a fact or reality such as 'know' and 'realize' which have the certain meaning that can be considered as a fact and truth.

Example:

Andi seems to have a fever and does not realize that there is heavy rain outside.

In the sentence above the presuppositions are:

(a) Andi has a fever.

(b) Outside is heavy rain. 
That statement becomes factual because it has been mentioned in speech. The use of the words 'know', 'conscious', 'want' are words that express something that is implied as a fact of a speech.

\subsubsection{Lexical Presupposition}

This presupposition is a presupposition obtained through speech interpreted through affirmation in speech. It is interpreted by the presupposition that another meaning can be understood by the hearer and it uses the lexical items such as 'stop', 'start', and 'again'.

Example:

Andi quit smoking after being laidoff.

The presuppositions of the above utterances are:

(a) Andi used to smoke.

(b) Andi used to work.

The presupposition arose with the use of the word 'stop' and laid-off, which stated that Andi had smoked and worked before, but now it no longer exists.

\subsubsection{Structural presupposition}

This is expressed through speech whose structure is clear and immediately understood. What questions are asked, who, where, why and how to show the presuppositions that arise from the speech.

Example:

What's in the closet?

The above statement shows presuppositions:

(a) There is something stored in the closet.
A presupposition that states 'something' is an object that is spoken and understood by speakers through a question sentence structure that asks 'what'.

\subsubsection{Non-factive Presupposition}

Non-factive presupposition is assumed not to be real. The verbs such as 'dream', 'imagine', and 'pretend' are used to describe something that is not true and can not give the real description of utterance.

Example:

I wish I had a car.

From the utterances above the presupposition that arises is:

a. I don't have a car.

The use of the word 'wish' as presupposition can give rise to nonfactual presuppositions.

\subsubsection{Counterfactual Presupposition}

This presumption produces an understanding that is contrary to the statement or contradictory. Conditions that produce presuppositions such as these usually contain "if-clause".

Example:

If today Sinta came, he would meet Andi.

From the example above, the presuppositions that appear are:

(a) Sinta was not coming.

(b) Sinta did not meet Andi.

The presumption arises from sentence contradictions with the use of the word 'if'. 


\section{RESEARCH METHOD}

This research uses the qualitative descriptive method which collects the data by observation in news. Bogdan and Taylor (as cited in Meleong, 2002) stated qualitative research method is defined as a research procedure which produces descriptive data in the form of words written or spoken of the person. According to Arikunto (2010) descriptive research is the study intended to investigate the situation, condition, circumstances, events, and other activities, and the result presented in the form of the research report. This research will be done by non-participant observation.

After collecting the data, the researcher takes the next step that is analyzing the data. According to Sudaryanto (2015) there are two methods to analyze data, they are agih and padan method. In this research, agih method is used to analyze the type, while padan method is used to analyze the meaning of the utterance. Then, the researcher will present the result. There are two methods to present the data analysis (Sudaryanto, 1993, p. 144). The methods are formal and informal method. The result of this research will be presented informally, because the result will be in the form of words.

\section{FINDINGS AND DISCUSSION}

\subsection{Existential Presupposition}

Data 1: However one alleged party the long-running domestic separatist group, OPM, - has rejected the announcement as "lies and fabrication".

Presupposition:

- There is a separatist group.

- A separatist group named OPM exists.

The above presuppositions are included in existential presupposition, because it contains the existence of an entity that named by the speaker.

Data 2: It comes as Indonesian authorities increase efforts in their search for five soldiers and nine crews.

Presupposition:

- Indonesia exists.

- There are five soldiers and nine crews.

The above presuppositions are included in existential presupposition, because it contains the existence of an entity that named by the speaker.

Data 3: West Papua shares an island with Papua New Guinea.

Presupposition:

- There are more than one Papua.

- West Papua and New Guinea exist.

- There is an island.

The above presuppositions are included in existential presupposition, because it contains the existence of an entity that named by the speaker.

Data 4: The armed groups unified last month under the command of the 
United Liberation Movement for West Papua (ULMWP).

Presupposition:

- There are the armed groups.

- United Liberation Movement for West Papua (ULMWP) exists.

The above presuppositions are included in existential presupposition, because it contains the existence of an entity that named by the speaker.

Data 5: Politically and militarily we are united now.

Presupposition:

- There is politics.

- There is a military.

- We exist.

The above presuppositions are included in existential presupposition, because it contains the existence of an entity that named by the speaker.

Data 6: The international community can now see without a doubt that we are ready to take over our country.

Presupposition:

- There is an international community.

- There is a country.

The above presuppositions are included in existential presupposition, because it contains the existence of an entity that named by the speaker.

Data 7: Indonesia cannot stigmatize us as separatists or criminals anymore.

Presupposition:

- Indonesia exists.

- There are separatists.

- There are criminals.

The above presuppositions are included in existential presupposition, because it contains the existence of an entity that named by the speaker.

Data 8: The groups named include the military wing of the OPM, TPNPB, which attacked a construction site in December, reportedly killing 17 Indonesians.

Presupposition:

- Military wing of the OPM, TPNPB exists.

- There are Indonesians.

- There are 17 victims.

The above presuppositions are included in existential presupposition, because it contains the existence of an entity that named by the speaker.

Data 9: It must be stressed firmly that OPM TPN is not part of ULMWP.

Presupposition:

- OPM TPN and ULMWP exist.

- There are organizations.

The above presuppositions are included in Existential Presupposition, because the presupposition of the existence of an entity is named by speaker.

Data 10: ULMWP must stop using the name OPM TPN to gain political legitimacy at the international level. Presupposition:

- OPM TPN and ULMWP exist.

- There is a legitimacy..

The above presuppositions are included in existential presupposition, because it contains the existence of an entity that named by the speaker.

Data 11: Wenda and the ULMWP have been contacted for a response. Presupposition: 
- Wenda exists.

- ULMWP exists.

The above presuppositions are included in existential presupposition, because it contains the existence of an entity that named by the speaker.

Data 12: I personally have my doubts.

Presupposition:

- I exist.

- There are the doubts.

The above presuppositions are included in existential presupposition, because it contains the existence of an entity that named by the speaker.

Data 13: They operate within limited commands in discrete areas.

Presupposition:

- There is an operation.

- There are the commands.

- There is a discrete area.

The above presuppositions are included in existential presupposition, because it contains the existence of an entity that named by the speaker.

Data 14: He managed to cobble together the ULMWP from civilian representatives of the disparate Papua independence groups.

Presupposition:

- There is a civilian.

- There are Papuan independence groups.

The above presuppositions are included in existential presupposition, because it contains the existence of an entity that named by the speaker.

Data 15: The use of children as soldiers is a war crime under international law.

Presupposition:

- There are children
- There are soldiers.

- There are crimes.

- There is international law.

The above presuppositions are included in existential presupposition, because it contains the existence of an entity that named by the speaker.

Data 16: West Papua needs urgent international intervention, because child soldiers are themselves victims.

Presupposition:

- West Papua exists.

- There are children who are made soldiers.

- There are the victims.

The above presuppositions are included in existential presupposition, because it contains the existence of an entity that named by the speaker.

Data 17: The Indonesian government's security approach has created an intractable conflict by brutalizing generation after generation of West Papuans.

Presupposition:

- There is Indonesian government's security.

- There is a conflict.

- The brutalizing exists.

- West Papuans exist.

The above presuppositions are included in existential presupposition, because it contains the existence of an entity that named by the speaker.

Data 18: Reports of military and rebel violence in the region have continued through this year.

Presupposition:

- There are the reports.

- There is military violence.

- There is rebel violence.

- There is a region. 
The above presuppositions are included in existential presupposition, because it contains the existence of an entity that named by the speaker.

\subsection{Lexical Presupposition}

Data 1: A leading West Papuan independence organization claims tohave unified three rebel armies under its control.

Presupposition:

- Previously, the three rebel soldiers did not unite.

The above presuppositions are included in lexical presupposition, because it is expressed in an implied manner so that confirmation of the statement of utterance can be obtained after the statement of the utterance.

\subsection{Counterfactual Presupposition}

Data 1: We won't know if it's real until we see coordinated armed actions both in Nduga and beyond.

Presupposition:

- It is not real.

The above presupposition is included in counterfactual presupposition, because the presupposition produces an understanding that is contrary to the statement. Conditions that produce presuppositions such as these usually contain "if-clause" or presuppositions.

\section{CONCLUSION \\ SUGGESTION}

AND

The researcher has done the research about an analysis of presupposition found in the Guardian news: pragmatical approach. This research analyzes the types of presupposition and the mostly used type that exists in Guardian news. There are 18 types by existential presupposition, 1 type by lexical presupposition and 1 type by counterfactual presupposition found in the source of data. Existential presupposition are mostly occur in the Guardian news. It shows that presuppositions that assume the existence of something that indicate ownership or the existence of statements in speech are more commonly found in source of data.

Those who have the same problem and interested in conducting this research, it is suggested that this research can be a reference. Hopefully, there will be any further research for completing this topic to be better.

\section{REFERENCES}

Arikunto, S. (2010). Prosedur penelitian "suatu pendekatan praktis.” Jakarta: Rineka Cipta.

Levinson. (1983). Pragmatics. Cambridge: Cambridge University Press.

Meleong, L. J. (2002). Metodologi penelitian kualitatif. Bandung: Remaja Rosdakarya.

Sudaryanto. (1993). Metode dan aneka teknik analisis bahasa. Yogyakarta: Duta Wacana University Press.

Sudaryanto. (2015). Metode dan aneka teknik analisis bahasa. Yogyakarta: Sanata Dharma 
Crisnova Katalonika Siahaan, Zia Hisni Mubarak

University Press.

Yule. (1996). Pragmatics (1st ed.).

Oxford: Oxford University Press. 